\title{
Peran Resiliensi Karier sebagai Mediator antara Perceived Supervisor Support dan Employability Generasi Milenial
}

\section{Career Resilience as Mediator Between Perceived Supervisor Support and Employability of Millennials}

\author{
Hanum Adininggar ${ }^{1}$, Indrayanti ${ }^{2}$, Fathul Himam ${ }^{3}$ \\ Fakultas Psikologi, Universitas Gadjah Mada
}

Submitted 4 Maret $2020 \quad$ Accepted 22 Juni $2020 \quad$ Published 27 Oktober 2020

\begin{abstract}
Disruptive era forces millennials to enhance their competencies as an effort to survive and be exceptional both in labor market and workforce. In order to meet endless change of current demands, millennial as a generation dominating the workforce are expected to develop their competencies. This study aimed to explain how career resilience acts as mediator linking perceived supervisor support and employability of millennial workers, specifically in telecommunication sector. Data were collected from 218 millennial employees in various telecommunication industries in Indonesia through online survey (Google Form). Three scales were used to collect data, including Competence-Based Measurement of Employability that consists of 35 items, Survey of Perceived Supervisor Support that consists of 14 items, and Career Resilience Questionnaire that consists of 19 items. Result showed career resilience is not significant as full mediation. The direct effect of perceived supervisor support to employability is stronger when career resilience acts as a partial mediator. Further analysis and practical implication for organization and future research discussed.
\end{abstract}

Keywords: career resilience; employability; millennials; perceived supervisor support

Abstrak. Era disrupsi menuntut milenial untuk mengembangkan kompetensi dirinya (employability) agar mampu bertahan dalam lingkungan kerja dengan tuntutan pasar yang berubah-ubah. Penelitian ini bertujuan untuk menguji peran resiliensi karier sebagai mediator dalam hubungan perceived supervisor support terhadap employability generasi milenial yang bekerja di sektor telekomunikasi. Pengumpulan data dilakukan secara daring dengan melibatkan 218 pekerja milenial di perusahaan telekomunikasi. Employability diukur menggunakan skala CBME yang dimodifikasi dan terdiri atas 35 aitem, sedangkan perceived supervisor support diukur menggunakan skala modifikasi dari SPSS dengan aitem sebanyak 14, dan resiliensi karier diukur menggunakan skala CRQ yang dimodifikasi dan terdiri atas 19 aitem. Analisis data menggunakan teknik regresi secara bertahap. Berdasarkan hasil penelitian, diketahui resiliensi karier memiliki efek mediasi sebagian (parsial) dalam hubungan antara perceived supervisor support terhadap employability. Hal tersebut berarti bahwa pengaruh langsung perceived supervisor support terhadap employability lebih kuat dibandingkan pengaruh tidak langsung melalui resiliensi karier. Keterbatasan penelitian dan implikasi praktis dari penelitian ini dibahas lebih lanjut.

Kata kunci: employability; milenial; perceived supervisor support; resiliensi karier

${ }^{1}$ Korespondensi mengenai artikel ini dapat dilakukan melalui itshanum@gmail.com

2atau melalui indrapsi@ugm.ac.id 
Lingkungan kerja saat ini telah berubah dibandingkan dengan tahun-tahun sebelumnya (Berntson, Sverke, \& Marklund, 2006; Lyons, Schweitzer, \& Ng, 2015). Berkembangnya teknologi dan dimulainya era digitalisasi menuntut organisasi untuk menyesuaikan diri dengan perubahan tersebut. Hal tersebut di antaranya ditandai dengan lingkungan kerja yang fleksibel (Castells, 2000), frekuensi reorganisasi yang meningkat. Usaha lain yang organisasi lakukan untuk tetap dapat adaptif di lingkungan yang kerap berubah ialah dengan mulai mengurangi biaya tenaga kerja, dengan pemanfaatan teknologi maupun outsourcing. Kondisi tersebut akhirnya mengakibatkan menurunnya job security (Berntson, Sverke \& Marklund, 2006). Dampak perkembangan teknologi juga mengubah paradigma karier. Sebelumnya, karier dikelola dan dijamin peningkatannya oleh organisasi, namun saat ini dengan job security yang berkurang pula, karier menjadi tanggung jawab masing-masing individu. Dengan kata lain, pekerja sendirilah yang akan mengarahkan dan mengelola kariernya dan tidak lagi bisa bergantung pada organisasi. Pengaruh dari perubahan dan pertumbuhan ekonomi turut mengubah arah bisnis perusahaanperusahaan saat ini.

Tidak terkecuali pada perusahaan telekomunikasi, persaingannya dengan bisnis over-the-top (penyedia layanan streaming musik dan film, e-commerce, dsb.) sebagai dampak dari perkembangan teknologi yang pesat, menuntut individu dalam perusahaan telekomunikasi untuk terus meningkatkan kompetensi guna melaksanakan tugas-tugas yang semakin berkembang. Dalam rangka memenuhi permintaan yang semakin meningkat tersebut, perusahaan berlomba-lomba untuk mendapatkan sumber daya terbaik, termasuk sumber daya manusia. Dampak adanya perubahan lingkungan kerja tak hanya terasa pada perusahaan, tetapi juga dari sisi individu. Persaingan setiap perusahaan dalam mendapatkan sumber daya terbaik membuat individu, terutama milenial, perlu meningkatkan nilai keunggulannya agar dapat masuk ke dalam lingkungan kerja (Chiaburu, Baker, \& Pitariu, 2006).

Menurut Badan Pusat Statistik (2018), generasi milenial di Indonesia menempati sepertiga dari keseluruhan penduduk Indonesia dengan rincian persentase $33,75 \%$. Saat ini, sebanyak dua per tiga dari generasi milenial masuk dalam angkatan kerja (Badan Pusat Statistik, 2018), yang artinya cukup mendominasi dalam pasar tenaga kerja. Milenial semakin mendominasi lapangan kerja sebesar 35\% pada tahun 2019 (Pew Research Center, 2018). Lebih lanjut, diperkirakan generasi milenial akan menjadi tumpuan ekonomi negara hingga tahun 2025 (Badan Pusat Statistik, 2008). Bila potensi milenial dapat dioptimalkan, mereka tidak hanya dapat mendorong ekonomi tetapi juga menjadi penerus untuk memastikan keberlangsungan organisasi (Kaifi, Nafei, Khanfar, \& Kaifi, 2012). Namun demikian, keunggulan demografi ini belum didukung oleh kesesuaian kompetensi lulusan perguruan tinggi dengan kebutuhan industri saat ini (Badan Pusat Statistik, 2018).

Pada konteks kerja, milenial digambarkan sebagai individu yang 
mementingkan diri sendiri (Hill, 2008) dan tidak loyal terhadap pekerjaan serta memiliki komitmen organisasi yang rendah (Jacobson, 2007). Sebaliknya, milenial juga dianggap sebagai individu yang menghargai proses pembelajaran sehingga mereka cenderung mencari pengembangan diri di organisasinya (Kuron, Lyons, Schweitzer, \& Ng, 2015). Lebih lanjut, Kuron et al. (2015) mengungkapkan bahwa prioritas utama milenial dalam bekerja ialah kesempatan pengembangan dan pembelajaran, yang kemudian diikuti dengan keseimbangan kehidupan bekerja dan gaji. Kontras dengan generasi sebelumnya, milenial juga dianggap memiliki ekspektasi terhadap preferensi kerja (Ng, Schweitzer, \& Lyons, 2010).

Kondisi karier dan adanya kesenjangan kompetensi generasi milenial menuntut milenial untuk lebih fleksibel dalam menghadapi tantangan kerja saat ini. Di satu sisi, fleksibilitas ini menuntut individu untuk menyesuaikan diri secara proaktif sesuai kebutuhan organisasi dan disisi lain organisasi mampu meraih keunggulan kompetitif dengan memiliki karyawan yang fleksibel dalam menghadapi perubahan dan mengembangkan kompetensi (van Dam, 2004). van der Heijde \& van der Heijden, (2006) mendefiniskan employability sebagai pemenuhan, perolehan atau penciptaan pekerjaan secara terus menerus dengan mengoptimalkan kompetensi yang dimiliki individu.

Lebih lanjut, Van der Heijde dan van der Heijden merumuskan kompetensi individu yang dimaksud ke dalam tiga jenis kompetensi. Pertama, occupational expertise yang mengacu pada keahlian profesional individu yang di dalamnya terdapat pengetahuan dan keterampilan dalam bidang keahlian seseorang, serta pengakuan sosial dari profesional lain. Kedua, anticipation and optimization melibatkan persiapan individu dalam menghadapi perubahan yang akan datang secara proaktif dan kreatif, oleh karenanya individu mengusahakan hasil terbaik. Ketiga, personal flexibility berbicara mengenai keluwesan seseorang dalam menghadapi berbagai macam perubahan yang terjadi, tidak hanya dalam level pekerjaan tetapi juga perubahan internal dan eksternal bursa kerja. Berbeda dengan anticipation and optimization, personal flexibility lebih berfokus pada cara individu menanggapi perubahan secara pasif-reaktif.

Employability dapat dikembangkan lebih jauh dengan memberikan kesempatan belajar dalam program pengembangan karyawan juga dengan memberikan pekerjaan-pekerjaan yang menantang sebagai media implementasi pengetahuan dan keterampilan yang dimiliki individu (Pulakos, Arad, Donovan, \& Plamondon, 2000). Hal tersebut dapat tercapai dengan peran atasan yang memberikan pekerjaan yang menantang serta memperhatikan kompetensi dan peluang pengembangan karyawan. Ketika individu memersepsikan bahwa atasannya memberikan pekerjaan yang menantang dan peduli dengan kesejahteraannya (pengembangan karier), individu akan menukarnya dengan sikap positif dalam bekerja yang mampu mendorong employability (van der Heijden \& Bakker, 2011).

Hubungan individu dengan atasannya, dalam bentuk persepsi akan timbal balik yang diberikan atasan 
kepadanya selama bekerja disebut dengan perceived supervisor support (PSS). Menurut Eisenberger, Stinglhamber, Vandenberghe, Sucharski, \& Rhoades (2002), PSS yang dipersepsi dengan baik oleh individu secara tidak langsung mampu meningkatkan harapan individu bahwa usaha dan kerja keras yang ia lakukan akan diapresiasi. PSS dapat terwujud dalam dua hal, yakni 1) penilaian evaluatif terhadap atasan yang merupakan kepuasan terhadap individu sebagai anggota tim dan kinerjanya, apresiasi atas kerja keras individu, pertimbangan atasan akan nilai dan opini, pengayaan pekerjaan, kepuasan individu atas pekerjaannya, dan kesejahteraan individu; dan 2) tindakan yang mungkin dilakukan oleh atasan yang dapat memengaruhi individu dalam situasi tertentu seperti, kesediaan atasan dalam membantu permasalahan pekerjaan dan bantuan khusus, mengganti dengan pekerja yang dapat digaji lebih rendah, menanggapi keluhan individu, dan peningkatan kinerja.

Peran atasan sebagai penyedia dukungan dan sumber umpan-balik (Fugate, Kinicki, \& Ashforth, 2004) dari kinerja karyawan juga dapat membantu peningkatan kompetensi individu (Kidd \& Smewing, 2001). Senada dengan hal tersebut, karyawan yang mendapat informasi yang memadai mengenai karier dan dukungan dari atasan akan mencerminkan perilaku kerja yang positif (Bakker \& Demerouti, 2007), salah satunya proaktif yang merupakan kunci dari employability (Fugate et al., 2004). Rhoades dan Eisenberger (2002) menjelaskan bahwa karyawan memersepsi dukungan tersebut sebagai bentuk perhatian dan penghargaan atas keberadaan diri maupun kontribusi individu di organisasi. Ketika individu merasa terdukung, ia akan menunjukkan usahanya dalam meningkatkan dan mengembangkan kemampuannya (Eisenberger, Huntington, Hutchison, \& Sowa, 1986).

Penelitian oleh van Dam (2004) mengungkapkan bahwa dukungan atasan tidak berhubungan langsung dengan employability. Hal tersebut disebabkan oleh adanya perbedaan pandangan individu terhadap perubahan yang mengharuskan mereka menjaga employability-nya. Hal tersebut berarti bahwa tidak semua individu menerima perubahan secara terbuka, melainkan perubahan akan lebih dipersepsi sebagai situasi sulit. Oleh karena itu, dukungan atasan dianggap tidak cukup mampu mempengaruhi employability seseorang secara langsung karena adanya faktor dari dalam diri individu yang turut berperan.

Beberapa penelitian menunjukkan bahwa dukungan atasan mampu memengaruhi faktor internal individu (Kao, Rogers, Spitzmueller, Lin, \& Lin, 2014; Brotheridge \& Power, 2008), lebih spesifik memengaruhi cara pandang individu dalam menghadapi masalah sehingga ia lebih mampu menghadapi situasi sulit atau perubahan yang terjadi (Peters \& Pearce, 2012). Ketahanan untuk menghadapi situasi yang sulit tersebut disebut resiliensi karier (McLarnon \& Rothstein, 2013). Ketika individu mampu memandang perubahan secara lebih terbuka dan mampu menghadapi perubahan tersebut ia akan terdorong untuk meningkatkan kompetensi dalam rangka menjaga kelayakan kerjanya (employability). 
Wittekind, Raeder, dan Grote (2010) dalam penelitiannya pada 465 karyawan di Swiss menyebutkan bahwa dukungan untuk pengembangan karier dan keterampilan yang diberikan oleh organisasi dapat prediktor signifikan employability. Hal ini berarti bahwa semakin banyak dukungan yang diterima, akan semakin meningkat pula employability individu. Penelitian lain yang dilakukan oleh Bernstrøm, Drange, dan Mamelund (2018) kepada 10.000 karyawan kontrak menunjukkan bahwa karyawan dengan employability yang rendah cenderung mendapat dukungan yang kecil pula. Keterbatasan dalam metode membuat penelitian oleh Bernstrøm, Drange, dan Mamelund (2018) belum dapat membuktikan hubungan kausal di antaranya, namun diyakini kedua variabel ini memiliki hubungan. Menurut Drange, Bernstrøm, dan Mamelund (2018), hasil atas individu yang telah menerima dukungan adalah dengan meningkatnya employability. Adapun dukungan dalam penelitian ini yaitu berupa pemberian pelatihan oleh organisasi.

Investasi yang dilakukan oleh organisasi berupa pemberian dukungan manajerial pun memiliki hubungan dengan employability. Hal ini berdasarkan penelitian yang dilakukan oleh van Harten, Knies, dan Leisink (2015). Studi yang dilakukan dengan melibatkan 1.626 karyawan dari tiga rumah sakit di Belanda menunjukkan bahwa ketika dukungan atasan yang kuat diberikan, employability karyawan akan meningkat.

Studi kualitatif oleh Clarke (2017) kepada 23 partisipan lulusan tahun 20112013 menunjukkan bahwa kehadiran dukungan atasan akan berarti. Bila atasan tidak hadir, mereka mengalami kebingungan dan kewalahan selama mengerjakan tugas-tugasnya. Sebaliknya, bila atasan hadir dan memberi dukungan akan membantu mereka untuk tetap dapat bekerja secara optimal, serta lebih jauh mendukung mereka untuk bertahan dan menghadapi situasi karier yang terjadi, serta membantu mencapai karier secara lateral serta bertahan dalam pasar tenaga kerja. Hal tersebut dibuktikan oleh Todt, Weiss, dan Hoegl (2018) dengan melibatkan 238 karyawan di perusahaan perangkat lunak yang menunjukkan dukungan atasan lebih membantu dalam menghadapi permasalahan (resilien). Ketahanan serta kemampuan beradaptasi akan membantu individu mencapai employabilitynya (Fugate et al., 2004; Lyons et al., 2015).

London (1983) mendefinisikan resiliensi karier sebagai kemampuan individu untuk bertahan dalam perubahan karier di lingkungan yang kurang dari optimal. Menurutnya, individu yang resilien akan memiliki efikasi diri yang tinggi, berani mengambil risiko dan lebih mandiri. London (1983) juga menyebutkan bahwa resiliensi karier adalah lawan dari career vulnerability-kerapuhan psikologis (menjadi kesal dan sulit bekerja) ketika dihadapkan kondisi yang kurang optimal (halangan mencapai tujuan karier, ketidakpastian). Teori resiliensi karier kemudian terus dikembangkan, salah satunya oleh Fourie dan Van Vuuren (1998) yang mendefinisikan resiliensi karier sebagai kecenderungan individu dalam menghadapi paradigma karier dan situasi kerja yang berubah. Individu yang resilien digambarkan sebagai individu yang 
menunjukkan derajat fleksibilitas, adaptabilitas, dan kompetensi yang tinggi sekalipun dalam situasi karier yang sulit (Fourie \& Van Vuuren, 1998).

Penelitian oleh Todt, Weiss, dan Hoegl (2018) menunjukkan bahwa dukungan dari atasan dinilai lebih kuat dalam membantu individu menghadapi permasalahan yang dirasakan (resilien). Dukungan atasan yang dimaksud memiliki berbagai wujud, mulai dari pemberian tugas yang menarik (Meneghel et al., 2016), pemberian umpan-balik terhadap pekerjaan (Kuntz, Connell, \& Näswall, 2017), hingga dialog mengenai masalah pekerjaan maupun personal (Arora \& Rangnekar, 2014; Cameron \& Brownie, 2010; Lamb \& Cogan, 2016).

Berdasarkan uraian di atas, dukungan dari atasan (PSS) akan memengaruhi kesejahteraan yang kemudian dapat memberi dampak pada resiliensi individu. Lebih jauh lagi, individu yang resilien dan mampu menghadapi permasalahan (baik karier dan personal) akan mampu menunjukkan sikap positif dalam bekerja, terlebih dalam menghadapi perubahan yang terjadi dalam lingkungan pekerjaan, individu akan lebih positif memandang perubahan yang terjadi sehingga mendorong sikap proaktif untuk meningkatkan kompetensinya (employability). Selama ini, penelitian mengenai employability umumnya fokus kepada kaitannya dengan faktor internal individu, seperti trait kepribadian (Wille, De Fruyt, \& Feys, 2013), kecerdasan emosional (Di Fabio \& Bucci dalam Di Fabio, 2017), juga efikasi diri (Dacre Pool \& Qualter, 2013). Sementara sisi eksternal lebih menekankan perlunya peran dukungan organisasi untuk meningkatkan employability, tanpa memberi petunjuk lebih lanjut tingkat dukungan yang dibutuhkan untuk meningkatkan kemampuan diri yang dapat mendorong employability (Clarke, 2008). Sementara itu, penelitian lainnya lebih menjelaskan hubungan faktor internal dan eksternal terhadap employability secara teoritis, sementara penelitian ini dimaksudkan untuk memberikan bukti empiris kaitan faktor eksternal (perceived supervisor support) dan faktor internal (resiliensi karier) terhadap employability. Dengan demikian, studi ini dimaksudkan untuk menguji peran mediator dari resiliensi karier dalam hubungan antara perceived supervisor support dan employability. Hasil penelitian ini diharapkan mampu menambah bukti empiris peran dukungan supervisor dalam mewujudkan terjadinya resiliensi karier yang pada akhirnya akan meningkatkan daya kompetitif karyawan.

\section{Metode}

\section{Variabel penelitian}

Variabel tergantung dalam penelitian ini adalah employability yang didefinisikan sebagai tinggi rendahnya kompetensi yang dimiliki individu untuk mempertahankan dirinya di lingkungan kerja. Kompetensi yang dimaksud mengacu pada keahlian pekerjaan, antisipasi dan optimisasi, fleksibilitas pribadi, perasaan kepemilikan terhadap perusahaan dan keseimbangan. Employability dapat dilihat dari skor yang diperoleh oleh individu pada skala employability. Semakin tinggi skor employability yang diperoleh menunjukkan tingginya kompetensi individu untuk dapat dipertahankan di lingkungan kerja. 
Sebaliknya, semakin rendah skor employability individu menunjukkan kurangnya kompetensi yang dimiliki individu tersebut dalam bekerja.

Variabel bebas dalam penelitian ini adalah perceived supervisor support (PSS) yang diartikan sebagai positif-negatif persepsi individu mengenai penilaian supervisor kepadanya. Persepsi penilaian tersebut melibatkan keyakinan individu bahwa atasannya menghargai kontribusi yang ia berikan, menawarkan bantuan, dan memedulikan kesejahteraan subordinatnya. Skor PSS yang tinggi menunjukkan persepsi positif individu terhadap atasannya atau dengan kata lain individu merasa dipedulikan. Sebaliknya, skor yang rendah menunjukkan persepsi negatif individu kepada supervisor-individu tidak merasa dipedulikan supervisor.

Variabel mediator dalam penelitian ini adalah resiliensi karier yang diartikan sebagai tinggi rendahnya ketahanan individu dalam menghadapi perubahan yang terjadi dengan cepat utamanya dalam lingkungan kerja dan proses pencapaian karier. Hal tersebut dapat dilihat dari kepercayaan seseorang terhadap dirinya sendiri, kebebasan dalam menentukan kesuksesan karier, mengandalkan diri sendiri serta penerimaan akan perubahan. Semakin tinggi skor resiliensi karier yang diperoleh menunjukkan kemampuan penerimaan individu yang positif akan perubahan yang terjadi dalam kariernya. Sementara, semakin rendah skor resiliensi karier menunjukkan kerentanan individu dalam menghadapi perubahan dalam kariernya.

\section{Partisipan penelitian}

Subjek pada penelitian ini adalah milenial menurut Howe \& Strauss (2000) yaitu, mereka yang lahir pada tahun 1980-2000 (usia 18-39 tahun) yang telah bekerja di sektor telekomunikasi minimal satu tahun. Subjek yang berpartisipasi dalam penelitian ini sejumlah 206 orang, 169 subjek (82,04 \%) laki-laki. 122 dari total subjek $(59,22 \%)$ telah bekerja selama 1-5 tahun, dan 40,78\% telah bekerja selama $>5$ tahun. Berdasarkan rentang usia diketahui sebanyak 124 dari keseluruhan subjek $(60,19$ persen) berusia antara 25-32 tahun, 55 orang (26,70\%) berusia 33-39 tahun, dan 13,11\% lainnya berusia 18-24 tahun. Subjek berasal dari berbagai perusahaan telekomunikasi yang terdapat di Indonesia, baik BUMN maupun swasta. Pengumpulan data dilakukan secara dalam jaringan (daring) melalui Google Form yang dibagikan melalui pesan pribadi LinkedIn dan pesan terusan grup WhatsApp.

\section{Instrumen penelitian}

Penelitian ini menggunakan alat ukur sesuai teori yang diacu. Alat ukur-alat ukur tersebut telah digunakan dalam berbagai penelitian, baik yang dilakukan di negara Barat maupun Asia. Meskipun tidak menggunakan alat ukur yang sama, namun beberapa penelitian di Asia juga mengacu pada skala yang digunakan di negara Barat. Tien dan Wang (2017) yang mengeksplorasi employability dan resiliensi karir pada masyarakat Asia mengatakan bahwa meski budaya Asia cenderung kolektivis, masyarakat Asia tetap menunjukkan sisi kompetitif sebagai usaha untuk menunjukkan kinerja terbaik dan mencapai employability. Hal ini berarti bahwa variabel-variabel yang digunakan dalam 
penelitian ini dibutuhkan oleh individu di berbagai negara guna menjaga performa di tengah situasi karir yang berubah. Employability diukur menggunakan skala Competence-Based Measurement of Employability (CBME) dari van der Heijde dan van der Heijden (2006) yang telah dimodifikasi. CBME mengukur employability dari lima kompetensi, yaitu keahlian pekerjaan, antisipasi dan optimisasi, fleksibilitas pribadi, corporate sense, dan keseimbangan. Subjek dapat merespons pernyataan dalam CBME dengan memilih satu di antara lima alternatif jawaban: Sangat Tidak Sesuai, Tidak Sesuai, Netral, Sesuai, Sangat Sesuai. Setelah melalui proses uji-coba, diperoleh 35 aitem dengan daya diskriminasi aitem antara 0.275-0.687 dan Cronbach alpha sebesar 0.929 .

Perceived supervisor support (PSS) diukur menggunakan Scale of Perceived Supervisor Support (SPSS) milik Kottke dan Sharafinski (1988) yang telah dimodifikasi. SPSS merupakan skala pengukuran dukungan atasan yang disusun berdasarkan skala perceived organizational support yang telah dikembangkan terlebih dahulu oleh Eisenberger, et al. (1986). Pengukuran PSS didasarkan pada dua aspek yaitu, penilaian evaluatif terhadap atasan dan tindakan atasan yang dapat memengaruhi individu dalam situasi tertentu. Responden dapat memilih satu di antara lima jawaban yang tersedia, Sangat Tidak Sesuai, Tidak Sesuai, Netral, Sesuai dan Sangat Sesuai. Setelah skala melalui tahap uji-coba, didapatkan 14 aitem dengan daya diskriminasi aitem $0.544-0.870$ dan reliabilitas sebesar 0.945 .
Sementara itu, resiliensi karier diukur menggunakan Career Resilience Questionnaire milik Fourie dan Van Vuuren (1998) yang dimodifikasi. Resiliensi karier terdiri dari empat aspek yaitu, keyakinan terhadap diri sendiri, tidak mengandalakan kesuksesan karier tradisional, mengandalkan diri sendiri, dan reseptif terhadap perubahan. Sama seperti dua skala lainnya, pada skala resiliensi karier responden dapat memilih satu di antara lima pilihan respons yang tersedia, Sangat Tidak Sesuai, Tidak Sesuai, Netral, Sesuai dan Sangat Sesuai. Setelah melalui proses uji-coba, diperoleh daya diskriminasi aitem 0,273-0,648 dan Cronbach Alpha sebesar 0,837 .

\section{Analisis}

Data yang terkumpul kemudian dianalisis menggunakan analisis statistik. Adapun analisis statistik meliputi analisis statistik deskriptif untuk menggambarkan data yang diperoleh, serta analisis statistik inferensial untuk mengambil kesimpulan berdasarkan hipotesis yang telah diajukan. Teknik regresi secara bertahap dilakukan dalam pengujian hipotesis, mengingat terdapat satu variabel prediktor, satu variabel mediator dan satu variabel kriteria. Uji kesesuaian sebagai mediator dilakukan dengan memperhatikan beberapa kondisi sebagaimana menurut Baron dan Kenny (1986) berikut: (1) variabel independen mampu memengaruhi mediator, dengan cara meregresi variabel mediator dengan variabel prediktor; (2) variabel independen mampu menunjukkan pengaruh terhadap variabel dependen, dengan cara meregresi variabel dependen dengan variabel independen; (3) variabel mediator mampu 
Tabel 1.

Deskripsi Data Penelitian

\begin{tabular}{|c|c|c|c|c|c|c|c|c|c|}
\hline \multirow{2}{*}{ Variabel } & \multirow{2}{*}{$N$} & \multicolumn{4}{|c|}{$\begin{array}{c}\text { Data Hipotetis } \\
\text { Skor }\end{array}$} & \multicolumn{4}{|c|}{$\begin{array}{c}\text { Data Empiris } \\
\text { Skor }\end{array}$} \\
\hline & & $\begin{array}{c}X \\
\min \\
\end{array}$ & $\begin{array}{c}X \\
\max \end{array}$ & Mean & $S D$ & $\begin{array}{c}X \\
\min \\
\end{array}$ & $\begin{array}{c}X \\
\max \\
\end{array}$ & Mean & $S D$ \\
\hline Employability & 36 & 36 & 180 & 108 & 24 & 101 & 176 & 145,31 & 14,31 \\
\hline Resiliensi Karier & 17 & 17 & 85 & 51 & 11,33 & 87 & 150 & 120,97 & 10,91 \\
\hline $\begin{array}{l}\text { Perceived } \\
\text { Supervisor Support }\end{array}$ & 14 & 14 & 60 & 37 & 7,67 & 23 & 80 & 57,97 & 10,33 \\
\hline
\end{tabular}

memprediksi variabel dependen, hal ini dapat diketahui dengan cara meregresi variabel kriteria dengan variabel prediktor dan mediator. Baron dan Kenny (1986) menambahkan bahwa adanya asumsi variabel independen menyebabkan mediator menunjukkan kedua variabel ini berkorelasi. Korelasi antara variabel independen dan mediator menghasilkan multikolinearitas yang dapat dilihat ketika mengukur pengaruh kedua variabel tersebut dengan variabel dependen (Gambar 1).

\section{Hasil}

yang diperlukan dalam melakukan uji hipotesis. Uji asumsi meliputi uji normalitas, linearitas, dan multikolinearitas.

Uji normalitas bertujuan untuk melihat kenormalan sebaran data pada tiap variabel penelitian. Penelitian ini menggunakan teknik Kolmogorov-Smirnov dengan z-score dalam menguji normalitas. Data terdistribusi normal apabila $p>0,05$ (Field, 2009). Hasil uji normalitas menggunakan $z$-score diketahui bahwa $p=$ 0,200 yang berarti sebaran data normal.

Uji linearitas dilakukan untuk mengetahui hubungan antar variabelvariabel yang diukur dalam satu garis yang

Tabel 2.

Hasil Uji Linearitas

\begin{tabular}{lccc}
\hline \multicolumn{1}{c}{ Variabel Prediktor } & $\begin{array}{c}\text { Koefisien } \\
\text { Linearitas }(\boldsymbol{F})\end{array}$ & Signifikansi $(\boldsymbol{p})$ & Keterangan \\
\hline Resiliensi Karier & 99,177 & 0,00 & Linear \\
Perceived Supervisor Support & 67,883 & 0,00 & Linear \\
\hline
\end{tabular}

Deskripsi data penelitian dapat digunakan untuk mengetahui informasi-informasi mengenai keadaan sampel pada tiap variabel penelitian. Deskripsi tersebut dapat berisikan informasi seperti rerata (mean) dan standar deviasi, baik secara hipotetis maupun empiris. Tabel 1 menggambarkan data dalam penelitian ini.

Uji asumsi dilakukan untuk memastikan dan memenuhi syarat-syarat linear. Hasil uji linearitas menunjukkan hubungan yang linear antar masing-masing variabel prediktor terhadap variabel dependen $(F=99,177$ dan $F=67,883 ; p<$ $0,05)$. Tabel 2 merupakan hasil uji linearitas.

Uji multikolinearitas umum dilakukan dalam uji regresi untuk mengetahui kekuatan hubungan antara dua atau lebih variabel bebas. Hasil uji 
multikolinearitas dapat diketahui dengan melihat nilai VIF dan tolerance masingmasing variabel penelitian. Field (2009) mengatakan bahwa suatu variabel tidak terindikasi multikolinearitas apabila memiliki nilai VIF $<10$ dan tolerance $>0,1$ (lihat Tabel 3). Di samping kedua nilai mampu memprediksi resiliensi karier secara signifikan $(b=0,193 ; p<0,05)$. Dengan demikian, syarat kondisi kedua (jalur-a signifikan) untuk analisis mediator dapat dipenuhi.

Langkah ketiga, meregresi variabel dependen (employability) dengan variabel

Tabel 3.

Hasil Uji Multikolinearitas

\begin{tabular}{lccc}
\hline \multicolumn{1}{c}{ Variabel } & Nilai Tolerance & VIF & Keterangan \\
\hline Resiliensi Karier & 0,963 & 1,039 & Tidak ada gejala \\
Perceived Supervisor Support & 0,963 & 1,039 & multikolinearitas \\
\hline
\end{tabular}

tersebut, koefisien korelasi antar variabel juga dapat menunjukkan indikasi atau gejala multikolinearitas (lihat Tabel 4).

Setelah melakukan dan memastikan bahwa setiap uji asumsi terpenuhi, selanjutnya peneliti melakukan uji hipotesis. Uji hipotesis dilakukan dengan analisis mediasi menurut Baron dan Kenny (1986). Pertama, mengestimasi jalur c, meregresi employability dengan PSS sebagai prediktor. Perceived supervisor support berpengaruh secara signifikan terhadap employability, dengan nilai independen (perceived supervisor support) dengan mediator (resiliensi karier) sebagai prediktor. Langkah ini akan menghasilkan dua nilai estimasi prediktor yaitu, prediksi variabel mediator (resiliensi karier) terhadap variabel dependen (employability) yang disebut jalur-b, serta prediksi variabel independen (perceived supervisor support) terhadap variabel dependen (employability) setelah dimasukkan variabel mediator (resiliensi karier) yang dapat disebut jalur$c^{\prime}$. Tabel 5 menunjukkan resiliensi karier mampu memprediksi employability secara

Tabel 4.

Matriks Korelasi

\begin{tabular}{|c|c|c|c|c|c|}
\hline & & \multicolumn{2}{|c|}{ Employability } & Resiliensi Karier & PSS \\
\hline \multirow{3}{*}{$\begin{array}{l}\text { Korelasi } \\
\text { Pearson }\end{array}$} & Employability & \multicolumn{2}{|l|}{1,000} & 0,552 & 0,483 \\
\hline & Resiliensi Karier & \multicolumn{2}{|l|}{0,552} & 1,000 & 0,193 \\
\hline & PSS & \multicolumn{2}{|l|}{0,483} & 0,193 & 1,000 \\
\hline \multirow{3}{*}{\multicolumn{3}{|c|}{$\begin{array}{l}\mathrm{b}=0,483(\mathrm{p}<0,05) . \text { Hal tersebut berarti, syarat } \\
\text { kondisi pertama (jalur-c signifikan) untuk } \\
\text { analisis mediator dapat dipenuhi. }\end{array}$}} & \multirow{4}{*}{\multicolumn{3}{|c|}{$\begin{array}{l}\text { signifikan }(b=0,476 ; p<0,05) \text {. Dengan } \\
\text { demikian, syarat kondisi ketiga (jalur-b } \\
\text { signifikan) untuk analisis mediator dapat } \\
\text { dipenuhi. }\end{array}$}} \\
\hline & & & & & \\
\hline & & & & & \\
\hline \multicolumn{3}{|c|}{ Kedua, mengestimasi jalur a, } & & & \\
\hline \multicolumn{6}{|c|}{ meregresi variabel mediator (resiliensi } \\
\hline \multicolumn{6}{|c|}{ karier) dengan variabel independen } \\
\hline \multicolumn{6}{|c|}{ (perceived supervisor support) sebagai } \\
\hline \multicolumn{6}{|c|}{ prediktor. Perceived supervisor support } \\
\hline
\end{tabular}


Tabel 5.

Hasil Regresi Jalur-b dan Jalur-c'

\begin{tabular}{lccccc}
\multicolumn{1}{c}{ Variabel } & $\boldsymbol{B}$ & $\boldsymbol{\beta}$ & $\boldsymbol{t}$ & $\boldsymbol{p}$ & $\boldsymbol{R}^{2}$ \\
\hline Resiliensi Karier & 0.466 & 0.476 & 9.000 & 0.000 & \multirow{2}{*}{0.452} \\
Perceived supervisor support & 0.382 & 0.391 & 7.394 & 0.000 & \\
\hline
\end{tabular}

Variabel dependen: employability

Tabel 5 menunjukkan bahwa meskipun resiliensi karier mampu memprediksi employability secara signifikan $(b=0,476 ; p<0,05)$, namun PSS juga masih mampu memprediksi employability secara signifikan $(b=0,391 ; p<0,05)$. Dengan demikian, syarat kondisi keempat (jalur-c' tidak signifikan) tidak dapat terpenuhi, mengingat nilai PSS tetap signifikan meskipun sudah dimasukkan variabel mediasi resiliensi karier dalam hubungannya dengan employability. Hal tersebut dapat disebabkan adanya hubungan yang lemah antara perceived supervisor support dan resiliensi karier dengan $r=0,193$ (lihat Tabel 4).

\section{Diskusi}

Penelitian ini bertujuan untuk mengetahui efek mediasi variabel resiliensi karier dalam hubungan perceived supervisor support dan employability pada generasi milenial di perusahaan telekomunikasi. Berdasarkan hasil penelitian, diketahui bahwa resiliensi karier menunjukkan efek mediasi sebagian (parsial) antara perceiver supervisor support terhadap employability. Hal ini berarti bahwa pengaruh langsung perceived supervisor support terhadap employability milenial lebih kuat dibandingkan pengaruh tidak langsungnya melalui resiliensi karier. Dengan demikian, dapat dikatakan bahwa hipotesis yang diajukan dalam penelitian ini, yaitu: resiliensi karier mampu memediasi penuh hubungan antara perceived supervisor support terhadap employability milenial ditolak.
Hasil penelitian menunjukkan bahwa perceived supervisor support (PSS) mampu memengaruhi employability dengan sumbangan efektif sebesar $23,4 \%$ dan koefisien regresi sebesar 0,483 yang membuktikan adanya hubungan antara PSS dan employability. Hasil ini senada dengan penelitian sebelumnya oleh Van Bloois, De Pater, \& Nauta (2010) yaitu, employability dapat dicapai salah satunya melalui relasi dalam pekerjaan berupa pertukaran sosial yang terjadi antara karyawan dan atasan. Adanya relasi dalam pekerjaan yang dibangun antara karyawan dan atasan dapat memengaruhi penilaian atasan terhadap bawahannya, yang kemudian secara lebih lanjut dapat menjadi persepsi karyawan akan dukungan atasannya (Eisenberger et al., 2002).

Persepsi dukungan atasan dalam penelitian ini berperan sebagai sumber daya eksternal individu dan dapat dirasakan salah satunya melalui pemberian umpan balik pekerjaan oleh atasan. Hasil penelitian ini menguatkan penelitian yang telah dilakukan oleh van Emerik, Schreurs, de Cuyper, Jawahar dan Peeters (2012) yaitu, bahwa dukungan atasan dalam bentuk umpan balik memiliki korelasi yang kuat terhadap employability seseorang. Hal ini dikarenakan, ketika seseorang merasa diperhatikan dan didukung, ia akan lebih memaknai pekerjaannya dan mendorong dirinya untuk terus mengembangkan kemampuan yang dapat menunjang dalam pekerjaan (van Emerik et al., 2012). Penguatan relasi antara atasan dan karyawannya berpotensi untuk memberi dampak signifikan terhadap 
pengembangan kompetensi karyawan sebagai sumber keunggulan kompetitif organisasi (Clarke, 2008).

Bentuk lain dari dukungan atasan yang dapat dirasakan oleh karyawan adalah kepedulian atasan akan kesejahteraan karyawannya. Hal ini dapat tercermin melalui aktivitas pembelajaran dan pengembangan, seperti coaching dan mentoring serta pemberian tugas-tugas yang menarik. Hasil penelitian oleh van Emmerik et al. (2012) juga mendukung hasil penelitian Rousseau, Ho, dan Greenberg (2006) dan Wittekind, Raeder, dan Grote (2010) yang mengatakan bahwa pemberian dukungan dalam bentuk tersebut dapat menjadi prediktor signifikan dan meningkatkan employability individu seiring bertumbuhnya perasaan dihargai pada diri karyawan.

Milenial memiliki kebutuhan sosial yang tinggi, ikatan yang kuat dengan rekan kerja, dan orientasi kelompok yang kuat (Borges, Manuel, Elam, \& Jones, 2010) sehingga mereka senang memiliki rekan kerja yang ramah, serta menyukai lingkungan kerja yang menarik $(\mathrm{Ng}$, Schweitzer, \& Lyons, 2010). Dalam hal hubungan dengan rekan kerja, mereka juga digambarkan sebagai individu yang menginginkan komunikasi yang terbuka, positif, dan sering dilakukan (Howe \& Strauss, 2007). Hal ini kemudian membuat mereka berharap untuk dapat berkomunikasi dan membangun hubungan dengan atasan secara terbuka dan acap (Gursoy, Maier, \& Chi, 2008). Oleh karena itu, generasi milenial cenderung menginginkan situasi yang menekankan pada umpan-balik yang dapat diberikan dengan segera (Lowe, Levitt, \& Wilson,
2011). Mereka cenderung akan menghargai program pengembangan yang diberikan organisasi, mencari pekerjaan yang berarti serta menginginkan pekerjaan yang dapat memberi pemenuhan pribadi bagi dirinya (Hauw \& Vos, 2010). Selain itu dalam bekerja, milenial dapat termotivasi dengan pemberian tugas-tugas dan lebih menyukai komunikasi yang terbuka dan sering (Myers \& Sadaghiani, 2010).

Berbeda dengan penelitian yang dilakukan van Dam (2004) yang menunjukkan adanya hubungan tidak langsung antara dukungan atasan dan employability, penelitian ini menunjukkan adanya hubungan langsung yang lebih kuat antara keduanya dibandingkan dengan variabel mediator. Perbedaan hasil ini terjadi salah satunya karena mengingat karakteristik milenial yang mengandalkan atasannya sebagai sumber daya untuk berkembang dan menjaga employability-nya (Clarke, 2017). Meski terdapat pengaruh yang cukup kuat antara resiliensi karier dan employability, ketika resiliensi karier menjadi variabel mediator, pengaruhnya lebih kecil bila dibandingkan dengan variabel independen (PSS). Hal ini dapat disebabkan oleh hubungan antara perceived supervisor support dan resiliensi karier yang lemah. Hasil penelitian Brotheridge dan Power (2008) mengatakan adanya hubungan yang lemah antara dukungan atasan dan resiliensi karier. Hal tersebut dapat disebabkan oleh konsep resiliensi karier yang mengutamakan lingkungan kerja yang memberikan otonomi dan fleksibilitas bagi karyawannya (London, 1993; Noe, Noe, \& Bachhuber, 1990). Kedua hal tersebut cukup bertentangan dengan konsep PSS yang memungkinkan karyawan 
menjadi tergantung pada atasan dan tidak dapat mengelola pekerjaannya secara mandiri.

Hal lain yang dapat menjelaskan hal tersebut yaitu salah satu aspek dalam resiliensi karier yang bertentangan dengan konsep PSS, salah satunya adalah aspek self-reliance. Aspek self-reliance yang digambarkan sebagai pembebasan diri dari ketergantungan terhadap organisasi, salah satunya atasan, menjadi berlawanan ketika diteliti dengan PSS. Self-reliance fokus pada usaha yang berasal dari dalam diri, mengandalkan diri sendiri dalam menghadapi situasi kerja, sementara PSS merupakan dukungan yang tersedia dalam organisasi itu sendiri. Sehingga hal tersebut dapat mengurangi self-reliance individu.

Berdasarkan penelitian oleh Rigoni dan Adkins (2016) tentang keinginan milenial di tempat kerja, menyatakan bahwa $21 \%$ milenial melepaskan pekerjaannya saat ini dan mencari peluang pekerjaan baru. Lebih rinci lagi, sebagian besar lebih mencari peluang di luar tempat kerja terakhirnya, dan hanya beberapa yang mengambil pekerjaan baru dalam organisasi yang sama. Hal tersebut dilakukan karena adanya penawaran yang menarik dan sehingga membuat milenial tertarik. Adapun hal yang paling dapat menarik milenial adalah adanya kesempatan untuk belajar dan berkembang (Rigoni \& Adkins, 2016). Secara tidak langsung hal tersebut menunjukkan bahwa karier tidak menjadi fokus utama milenial, melainkan lebih pada kesempatan belajar dan berkembang yang ditawarkan oleh organisasi. Dapat dikatakan pula bahwa milenial tidak terpaku pada karier secara hierarki, melainkan secara lateral.
Skor employability yang tinggi pada penelitian ini menunjukkan tingginya kompetensi yang dimiliki oleh subjek penelitian untuk dapat bertahan di tempat kerja dan secara bersamaan pula dapat mendorong mereka untuk terus mencari pengembangan diri di tempat lain, terlepas sudah ada program pengembangan diri di tempat kerja saat ini. Skor PSS yang tinggi pun mengindikasikan bahwa milenial merasa didukung oleh atasannya. Namun demikian hal tersebut tidak menjamin milenial untuk bertahan di suatu tempat kerja. Mereka tidak cepat puas dan cukup dengan satu kesempatan belajar dan akan terus mencari kesempatan yang lebih baik di tempat baru (Rigoni \& Adkins, 2016). Temuan ini berkontribusi dalam memberikan penjelasan yang lebih luas lagi dalam memahami milenial di tempat kerja sekaligus membuka peluang bagi penelitian selanjutnya, terutama dalam memahami faktor lain yang menjadi alasan milenial bertahan atau berpindah tempat kerja, terlebih mengingat milenial dikenal sebagai 'kutu loncat'.

Terlepas dari kontribusi yang diberikan penelitian ini, ditemukan pula beberapa keterbatasan. Pertama, pengambilan data yang dilakukan secara daring sehingga tidak memberi peneliti kontrol yang penuh terhadap pemahaman subjek, meski telah disertakan petunjuk pengerjaan. Kedua, masa kerja yang tidak dihitung dari kali pertama responden bekerja, melainkan hanya pada masa kerja saat ini di perusahaan telekomunikasi.

\section{Kesimpulan}


Kesimpulan dalam penelitian ini adalah resiliensi karier tidak dapat memediasi secara penuh hubungan antara perceived supervisor support terhadap employability generasi milenial. Dengan kata lain, pengaruh langsung dari perceived supervisor support membuatnya lebih mendominasi hubungan terhadap employability dibandingkan pengaruh tidak langsung dari resiliensi karier.

Saran

Melihat pengaruh langsung perceived supervisor support yang lebih besar terhadap employability dibandingkan dengan pengaruh tidak langsung melalui resiliensi karier, organisasi dapat meningkatkan peran atasan terhadap karyawannya melalui berbagai upaya peningkatan kesejahteraan. Upaya-upaya tersebut dapat dilakukan dengan lebih menggalakkan coaching dan mentoring yang akan diberikan oleh atasan secara berkala dan pemberian tugas-tugas yang menantang bagi karyawan terutama milenial. Hal lain yang dapat dilakukan yaitu mengadakan sesi one-on-one secara rutin, baik formal ataupun informal kepada karyawan dan bersifat dua arah. Melalui sesi tersebut diharapkan dapat tercipta suasana diskusi yang kondusif dan mampu membantu kedua belah pihak.

Bagi peneliti selanjutnya, dapat menggunakan metode survei dengan melibatkan jumlah responden yang lebih banyak. Peneliti selanjutnya juga disarankan untuk menghitung rentang masa kerja responden yang dihitung dari pertama kali bekerja dalam melihat kaitannya dengan employability. Hal tersebut perlu dilakukan mengingat karakteristik milenial yang dianggap sebagai generasi yang senang berganti tempat kerja (kutu loncat) dalam dua tahun pertama masa pencarian dirinya di tempat kerja. Selain itu, adanya beberapa teori yang mengatakan bahwa employability dapat terkait dengan karakteristik individu, dapat menjadi pertimbangan bagi peneliti selanjutnya dalam menentukan variabel internal untuk membangun kesadaran selfemployability, dengan menggunakan metode eksperimen yang lebih aplikatif.

\section{Daftar Pustaka}

Arora, R., \& Rangnekar, S. (2014). Workplace mentoring and career resilience: An empirical test. The Psychologist-Manager Journal, 17(3), 205-220.

doi: https://doi.org/10.1037/mgr0000021

Badan Pusat Statistik. (2018). Statistik gender tematik: Profil generasi milenial Indonesia. Jakarta: Kementerian Pemberdayaan Perempuan dan Perlindungan Anak.

Bakker, A. B., \& Demerouti, E. (2007). The job demands-resources model: State of the art. Journal of Managerial Psychology, 22(3), 309-328. doi: https://doi.org/10.1108/026839407107 $\underline{33115}$

Baron, R. M., \& Kenny, D. A. (1986). The moderator-mediator variable distinction in social psychological research: Conceptual, strategic, and statistical considerations. Journal of Personality and Social Psychology, 51(6), 1173-1182. doi: 
https://doi.org/10.1037//0022-

$\underline{3514.51 .6 .1173}$

Bernstrøm, V. H., Drange, I., Mamelund, S.E. (2018). Employability as an alternate to job insecurity. Personnel Review, 48(1), 234-248. doi: https://doi.org/10.1108/PR-09-2017$\underline{0279}$

Berntson, E., Sverke, M., \& Marklund, S. (2006). Predicting perceived employability: Human capital or labour market opportunities?. Economic and Industrial Democracy, 27(2), 223-244. doi: https://doi.org/10.1177/0143831X060 $\underline{63098}$

Borges, N. J., Manuel, R. S., Elam, C. L., \& Jones, B. J. (2010). Differences in motives between millennial and generation $X$ medical students. Medical Education, 44(6), 570-576. doi: $\quad$ https://doi.org/10.1111/j.13652923.2010.03633.x

Brotheridge, C. M., \& Power, J. L. (2008). Are career centers worthwhile? Predicting unique variance in career outcomes through career centers usage. Career Developmental International, 13(6), 480-496. doi: https://doi.org/10.1108/136204308109 01651

Cameron, F., \& Brownie, S. (2010). Enhancing resilience in registered aged care nurses. Australasian Journal of Ageing, 29(2), 66-71. doi: https://doi.org/10.1111/j.17416612.2009.00416.x

Castells, M. (2000). The information age: Economy, society and culture. Oxford: Blackwell
Chiaburu, D. S., Baker, V. L., \& Pitariu, A. H. (2006). Beyond being proactive: What (else) matters for career selfmanagement behavviors? Career Development International, 11(7), 619632.

doi:

https://doi.org/10.1108/136204306107 $\underline{13481}$

Clarke, M. (2008). Understanding and managing employability in changing career contexts. Journal of European Industrial Training, 32(4), 258-284.

doi:

https://doi.org/10.1108/030905908108 $\underline{71379}$

Clarke, M. (2017). Building employability through graduate development programs: a case study in an Australian public sector organisation. Personnel Review, 46(4), 792-808. doi:10.1108/PR-12-20150321

Dacre Pool, L., \& Qualter, P. (2013). Emotional self-efficacy, graduate employability, and career satisfaction: Testing the associations. Australian Journal of Psychology, 65(4), 214-223. doi: https://doi.org/10.1111/ajpy.12023

Di Fabio, A. (2017). A review of empirical studies on employability and measures of employability. Dalam K. Maree, Psychology of Career Adaptability, Employability, and Career Resilience (hal. 107-124). Cham: Springer International Publishing.

Drange, I., Bernstrøm, V. H., \& Mamelund, S. (2018). Are you moving up or falling short? An inquiry of skillsbased variation in self-perceived employability among Norwegian 
employees. Work, Employment and Society, 32(2), 387-406. doi: https://doi.org/10.1177/095001701774 $\underline{9720}$

Eisenberger, R., Huntington, R., Hutchison, S., \& Sowa, D. (1986). Perceived organizational support. Journal of Applied Psychology, 71(3), 500-507. doi: $\quad$ https://doi.org/10.1037/0021$\underline{9010.71 .3 .500}$

Eisenberger, R., Stinglhamber, F., Vandenberghe, C., Sucharski, I. L., \& Rhoades, L. (2002). Perceived supervisor support: Contributions to perceived organizational support and employee retention. Journal of Applied Psychology, 87(3), 565-573. doi: $\quad$ https://doi.org/10.1037/00219010.87.3.565

Field, A. (2009). Discovering statistics using SPSS (Edisi ketiga). California: SAGE Publications Inc.

Fugate, M., Kinicki, A. J., \& Ashforth, B. E. (2004). Employability: A psychosocial construct, its dimensions, and applications. Journal of Vocational Behavior, 65(1), 14-38. doi: https://doi.org/10.1016/j.jvb.2003.10. $\underline{005}$

Fourie, C., \& Van Vuuren, L. (1998). Defining and measuring career resilience. SA Journal of Industrial Psychology, 24(3), 52-59. doi: http://dx.doi.org/10.1080/15555240.2 $\underline{015.1074052}$

Gursoy, D., Maier, T. A., \& Chi, C. G. (2008). Generational differences: An examination of work values and generational gaps in the hospitality workforce. International Journal of Hospitality Management, 27(3), 448-
458.

doi:

https://doi.org/10.1016/j.ijhm.2007.11 .002

Hauw, S. D., \& Vos, A. D. (2010). Millennials' career perspective and psychological contract expectations: Does the recession lead to lowered expectations? Journal of Business and Psychology, 25(2), 293-302. doi: https://doi.org/10.1007/s10869-0109162-9

Hill, L. A. (2008). Where will we find tomorrow's leaders? Harvard Business Review, 86(1), 123-138.

Howe, N., \& Strauss, W. (2007). Millennials Go to College. Great Falls, VA: LifeCourse Associates.

Howe, N., \& Strauss, W. (2000). Millennials Rising: The Next Great Generation. New York: Vintage Books.

Jacobson, W. S. (2007). Two's company, three's a crowd, and four's a lot to manage: Supervising in today's intergenerational workplace. Popular Government, 17, 18-23. Diakses melalui

https://www.researchgate.net/profil e/Willow_Jacobson/publication/2376 45570 Two's Company Three's a Crowd and Four's a Lot to Mana ge Supervising in Today's Interge nerational Workplace/links/54247b9 c0cf238c6ea6ecc0d.pdf

Kaifi, B. A., Nafei, W. A., Khanfar, N. M., \& Kaifi, M. M. (2012). A multigenerational workforce: Managing and understanding millennials. International Journal of Business and Management, 7(24), 88-93. doi: https://doi.org/10.5539/ijbm.v7n24p8 $\underline{8}$ 
Kao, K.-Y., Rogers, A., Spitzmueller, C., Lin, M.-T., \& Lin, C.-H. (2014). Who should serve as my mentor? The effects of mentor's gender and supervisory status on resilience in mentoring relationships. Journal of Vocational Behavior, 85(2), 191-203. doi:

https://doi.org/10.1037/mgr0000021

Kidd, J. M., \& Smewing, C. (2001). The role of supervisor in career and organizational commitment. European Journal of Work and Organizational Psychology, 10(1), 2540.

doi:

https://doi.org/10.1080/135943200420 $\underline{00016}$

Kottke, J. L., \& Sharafinski, C. E. (1988). Measuring perceived supervisory and organizational support. Educational and Psychological Measurement, 48(4), 1075-1079. doi: https://doi.org/10.1177/001316448848 $\underline{4024}$

Kuntz, J., Connell, P., \& Näswall, K. (2017). Workplace resource and employee resilience: The role of regulatory profiles. Career Development International, 22(4), 419-435. doi: https://doi.org/10.1108/CDI-11-2016$\underline{0208}$

Kuron, L. K., Lyons, S. T., Schweitzer, L., \& $\mathrm{Ng}$, E. S. (2015). Millennials' work values: Differences across the school to work transition. Personnel Review, 44(6), 991-1009. doi: https://doi.org/10.1108/PR-01-2014$\underline{0024}$

Lamb, D., \& Cogan, N. (2016). Coping with work-related stressors and building resilience in mental health workers:
A comparative focus group study using interpretative phenomenological analysis. Journal of Occupational and Organizational Psychology, 89(3), 474-492. doi: https://doi.org/10.1111/joop.12136

London, M. (1983). Toward a theory of career motivation. The Academy of Management Review, 8(4), 620-630. doi: https://doi.org/10.2307/258263

Lowe, D., Levitt, K. J., \& Wilson, T. (2011). Solutions for retaining Generation $Y$ employees in the workplace. IEEE Engineering Management Review, 39(2), 46-52. doi: https://doi.org/10.1109/EMR.2011.58 $\underline{76174}$

Lyons, S. T., Schweitzer, L., \& Ng, E. S. (2015). How have careers changed? An investigation of changing career patterns across four generations. Journal of Managerial Psychology, 30(1), 8-21. doi: https://doi.org/10.1108/JMP-07-2014$\underline{0210}$

McLarnon, M. J., \& Rothstein, M. G. (2013). Development and initial validation of the workplace resilience inventory. Journal of Personnel Psychology, 12(2), 63-73. doi: https://doi.org/10.1027/18665888/a000084

Meneghel, I., Martinez, I. M., \& Salanova, M. (2016). Job-related antecedents of team resilience and improved team performance. Personnel Review, 45(3), 505-522.

doi: https://doi.org/10.1108/PR-04-2014$\underline{0094}$

Myers, K. K., \& Sadaghiani, K. (2010). Millennials in the workplace: A 
communication perspective on Millennials' organizational relationships and performance. Journal of Business and Psychology, 25, 225-238. doi:10.1007/s10869-0109172-7

Ng, E. S., Schweitzer, L., \& Lyons, S. T. (2010). New generation, great expectations: A field study of the millennial generation. Journal of Business and Psychology, 25(2), 281292. doi:10.1007/s10869-010-9159-4

Noe, R. A., Noe, A. W., \& Bachhuber, J. A. (1990). An investigation of the correlates of career motivation. Journal of Vocational Behavior, 37(3), 340-356. doi:

https://doi.org/10.1016/00018791(90)90049-8

Peters, J., \& Pearce, J. (2012). Relationships and early career teacher resilience: A role for school principals. Teachers and Teaching: Theory and Practice, 18(2), 249-262. doi: https://doi.org/10.1080/13540602.201 $\underline{2.632266}$

Pew Research Center. (2018). Millennials are the largest generation in the U.S. labor force. Diakses melalui https://www.pewresearch.org/facttank/2018/04/11/millennials-largestgeneration-us-labor-force/

Pulakos, E. D., Arad, S., Donovan, M. A., \& Plamondon, K. E. (2000). Adaptability in the workplace: Development of a taxonomy of adaptive performance. Journal of Applied Psychology, 85(4), 612-624. doi: $\quad$ https://doi.org/10.1037/0021$\underline{9010.85 .4 .612}$
Rhoades, L., \& Eisenberger, R. (2002). Perceived organizational support: A review of the literature. Journal of Applied Psychology, 87(4), 698-714. doi: $\quad$ https://doi.org/10.1037/00219010.87.4.698

Rigoni, B., \& Adkins, A. (2016). What millennials want from a new job. Harvard Business Review. Diakses melalui

https://www.mtwcare.org/uploads/8 19/8/6/89863841/what millennials w ant from a new job.pdf

Rousseau, D. M., Ho, V. T., \& Greenberg, J. (2006). I-deals: idiosyncratic terms in employment relationship. Academy of Management Review, 31(4), 977-994. doi:

https://doi.org/10.5465/amr.2006.225 $\underline{27470}$

Tien, H.-L.S., \& Wang, Y.-C. (2017). Career adaptability, employability, and career resilience of Asian people. Dalam K. Maree, Psychology of Career Adaptability, Employability, and Resilience (hal. 299-314). Cham: Springer International Publishing

Todt, G., Weiss, M., \& Hoegl, M. (2018). Mitigating negative side effects of innovation projects terminations: The role of resilience and supervisor support. The Journal of Product Innovation Management, 35(4), 518542. doi: https://doi.org/10.1111/jpim.12426

Van Bloois, R., De Pater, I., \& Nauta, A. (2010). The route to employability: individually designed or relationally negotiated? IACM 23 $3^{\text {rd }}$ Annual Conference Paper. doi: 
http://dx.doi.org/10.2139/ssrn.161519 $\underline{7}$

van Dam, K. (2004). Antecedents and consequences of employability orientation. European Journal of Work and Organizational Psychology, 13(1), 29-51.

doi: https://doi.org/10.1080/135943203440 $\underline{00237}$

van der Heijde, C. M., \& van der Heijden, B. I. (2006). A competence-based and multidimensional operationalization and measurement of employability. Human Resource Management, 45(3), 449-476. doi: https://doi.org/10.1002/hrm.20119 van der Heijden, B. I., \& Bakker, A. B. (2011). Toward a mediation model of employability enhancement: A study of employee-supervisor pairs in the building sector. The Career Development Quarterly, 59(3), 232248. doi:

https://doi.org/10.1002/j.21610045.2011.tb00066.x

van Emerik, I. H., Schreurs, B., de Cuyper, N., Jawahar, I. M., \& Peeters, M. C. (2012). The route to employability:
Examining resources and the mediating role of motivation. Career Development International, 17(2), 104119. doi: https://doi.org/10.1108/136204312112 25304

van Harten, J., Knies, E., Leisink, P. (2015). Employer's investments in hospital workers' employability and employment opportunities. Personnel Review, 45(1), 84-102. doi: https://doi.org/10.1108/PR-05-2014$\underline{0115}$

Wille, B., De Fruyt, F., \& Feys, M. (2013). Big five traits and intrinsic success in the new career era: A 15-Year longitudinal study on employability and Work-Family conflict. Applied Psychology, 62(1), 124-156. doi: https://doi.org/10.1111/j.14640597.2012.00516.x

Wittekind, A., Raeder, S., Grote, G. (2010). A longitudinal study of determinants of perceived employability. Journal of Organizational Behavior, 31(4), 566$586 . \quad$ doi: https://doi.org/10.1002/job.646 